\title{
$\mathrm{Ti}$ 첨가 가속냉각형 고장력강의 용접열영향부 연화에 미치는 질소함량의 영향
}

\author{
방국수 $^{1, *} \cdot$ 정호신 $^{2} \cdot$ 박찬 $^{2}$ \\ ${ }^{1}$ 부경대학교 신소재시스템공학과 \\ ${ }^{2}$ 부경대학교 재료공학과
}

\section{Effects of Nitrogen Content on the HAZ Softening of Ti-Containing High Strength Steels Manufactured by Accelerated Cooling}

\author{
Kook-soo Bang ${ }^{1, *}$, Ho-shin Jung ${ }^{2}$, and Chan Park ${ }^{2}$ \\ ${ }^{1}$ Dept. of Materials System Eng., Pukyong National University, Busan 48547, Republic of Korea \\ ${ }^{2}$ Dept. of Materials Sci. and Eng., Pukyong National University, Busan 48547, Republic of Korea
}

\begin{abstract}
The effects of nitrogen content on the HAZ softening of Ti-containing high strength steels manufactured by accelerating cooling were investigated and interpreted in terms of the microstructures in the softening zone. Regardless of their content, all of the steels investigated showed a softened zone 9-10 $\mathrm{mm}$ wide. The minimum hardness in the zone, however, was different, with lower hardness in the higher nitrogen content steel. Microstructural observations of the steel showed that the amount of soft ferrite was increased in the zone with an increase of nitrogen content of the steel, suggesting that microstructural evolution in the HAZ is influenced by the nitrogen content. Measurements of TiN particles showed that the degree of particles coarsening in the HAZ was lower in the higher nitrogen content steel. Therefore, it is believed that finer TiN particles in the HAZ inhibit austenite grain growth more effectively, and lead to an accelerated ferrite transformation in higher nitrogen content steel, resulting in a higher amount of soft ferrite microstructure in the softened zone.
\end{abstract}

(Received August 4, 2016; Accepted August 31, 2016)

Keywords: alloys, welding, microstructure, hardness test, HAZ softening

\section{1. 서 론}

고장력강의 강도와 인성 향상을 위하여 적정의 합금원소 첨가와 제조방법의 개선에서 많은 진보가 이루어져 왔다. 특 히 강압하/가속냉각의 제조방법으로 만들어지는 고장력강은 통상의 압연방법으로 제조되는 강에 비하여 페라이트가 미 세하고 소량의 베이나이트를 포함하여 높은 강도와 인성을 나타낸다. 하지만 이런 방법으로 제조된 강을 높은 입열량으 로 용접하면 용접열영향부 (Heat affected zone, HAZ)의 강도 가 원래의 모재 보다 낮아지는 소위 HAZ 연화현상이 생긴다 [1-4]. 즉 용접 가열/냉각과정 중 페라이트가 원래의 크기보 다 성장하고 베이나이트가 소실하는 영역이 존재하여 강도 가 원래의 모재보다 저하하게 된다. 한 예로 Nitoh 등은 [4]

*Corresponding Author: Kook-soo Bang

[Tel: +82-51-629-6379, E-mail: ksbang@pknu.ac.kr]

Copyright (c) The Korean Institute of Metals and Materials
가속냉각으로 제조된 인장강도 $500 \mathrm{MPa}$ 급 강을 3 전극 편면 1 층으로 서브머지드용접하여 용접이음부 경도를 측정한 결과 $\mathrm{HAZ}$ 의 최저경도가 모재 보다 약 $20 \mathrm{Hv}$ 저하한다고 보고하였 다. HAZ에 이러한 연화영역이 존재하여도 폭이 넓은 판을 사용하는 실제 구조물에서는 용접이음부 강도저하가 크지 않다고 보고되고 있으나 [5], 가속냉각형 강을 사용하는 경우 $\mathrm{HAZ}$ 에서 연화의 정도를 파악하는 것은 여전히 중요하다.

한편 고장력강 $\mathrm{HAZ}$ 중 특히 용융선에 가까운 곳에서는 가 열온도가 높고 냉각속도가 빨라 결정립이 매우 조대화하고 베이나이트 등 취약한 저온변태조직이 형성하여 인성이 매 우 떨어진다. 이런 문제점을 해결하기 위하여 가장 널리 행해 지는 방법의 하나는 강 중에 합금원소 $\mathrm{Ti}$ 를 미량 첨가하는 것 이다. $\mathrm{Ti}$ 는 강 중에서 $\mathrm{N}$ 과 결합하여 극히 안정한 $\mathrm{TiN}$ 을 석출 하여 용접가열 중 결정립 성장을 억제하고 동시에 냉각 중 페 라이트를 불균질 핵생성시켜 조직을 조대한 베이나이트 대 
Table 1. Chemical compositions and tensile properties of the steels used

\begin{tabular}{c|c|c|c|c|c|c|c|c|c}
\hline \multirow{2}{*}{ Steel } & \multicolumn{4}{|c|}{ Chemical composition (wt\%) } & \multicolumn{3}{c}{ Tensile properties } \\
\cline { 2 - 10 } & $\mathrm{C}$ & $\mathrm{Si}$ & $\mathrm{Mn}$ & $\mathrm{Al}$ & $\mathrm{Ti}$ & $\mathrm{N}$ & $\begin{array}{c}\mathrm{TS} \\
(\mathrm{MPa})\end{array}$ & $\begin{array}{c}\text { YS } \\
(\mathrm{MPa})\end{array}$ & $\begin{array}{c}\mathrm{El} \\
(\%)\end{array}$ \\
\hline $\mathrm{A}$ & 0.11 & 0.11 & 1.49 & 0.03 & 0.013 & 0.003 & 509 & 430 & 33 \\
\hline $\mathrm{B}$ & 0.11 & 0.11 & 1.51 & 0.02 & 0.015 & 0.010 & 511 & 439 & 36 \\
\hline $\mathrm{C}$ & 0.12 & 0.10 & 1.53 & 0.02 & 0.016 & 0.014 & 510 & 448 & 33 \\
\hline $\mathrm{D}$ & 0.10 & 0.11 & 1.51 & 0.02 & 0.015 & 0.024 & 508 & 454 & 38 \\
\hline
\end{tabular}

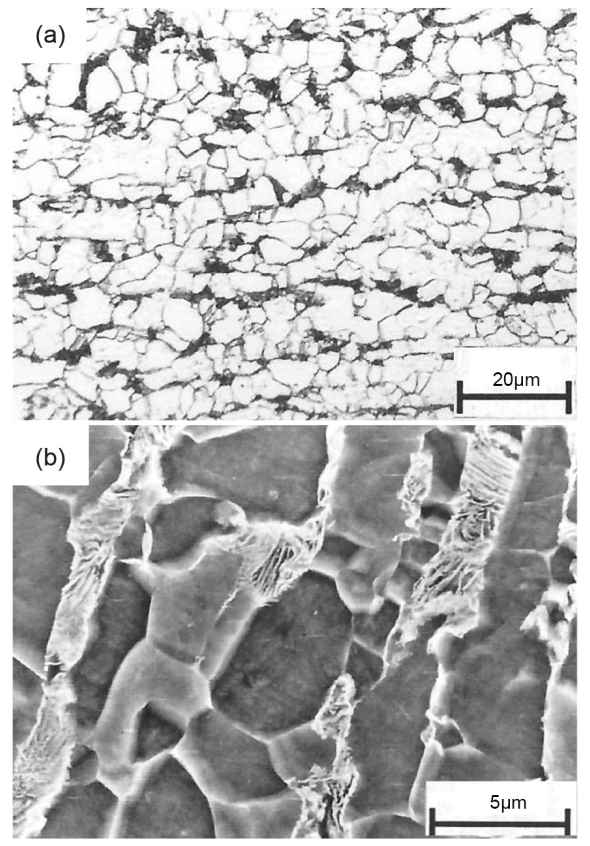

Fig. 1. Typical (a) optical and (b) SEM micrographs of the steels.

신 페라이트가 포함된 미세한 조직으로 만들어 인성을 향상 시킨다고 잘 알려져 있다. 이러한 TiN 효과를 최대로 하기 위 하여 $\mathrm{Ti}$ 와 $\mathrm{N}$ 의 적정 첨가량에 대한 많은 연구가 행하여져 왔 다 [6-11]. Kasamatsu 등은 [8] Ti가 약 $0.015 \%$ 첨가되는 경우 $\mathrm{N}$ 이 약 $0.005 \%$ 에서 $\mathrm{TiN}$ 이 가장 미세분산 석출하여 인성이 가장 우수해진다고 하였다. 이러한 $\mathrm{Ti}$ 와 $\mathrm{N}$ 함량은 두 원소의 화학양론적 비인 3.4에 근사하여, 일정한 $\mathrm{Ti}$ 함량에서 과잉의 $\mathrm{N}$ 첨가는 바람직하지 않다고 하였다. 하지만 최근 Choi 등은 [9] 화학양론적 비보다 높은 $\mathrm{N}$ 함량이 용접가열 과정 중 $\mathrm{TiN}$ 의 성장을 억제하여 과잉의 $\mathrm{N}$ 첨가가 조직개선에 오히려 효 과적이라고 발표하였다.

본 연구에서는 $\mathrm{Ti}$ 을 첨가하여 강압하/가속냉각으로 제조 한 인장강도 $500 \mathrm{MPa}$ 급 고장력강을 대상으로 열영향부 연화 에 미치는 $\mathrm{N}$ 함량의 영향에 대하여 조사하였다. 앞서 설명한 바와 같이 $\mathrm{Ti}$ 첨가강에서 $\mathrm{N}$ 함량이 $\mathrm{HAZ}$ 조직에 영향을 미친

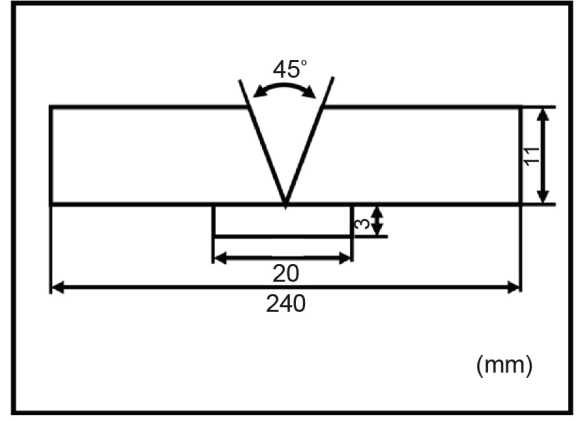

Fig. 2. Joint configuration for the weld.

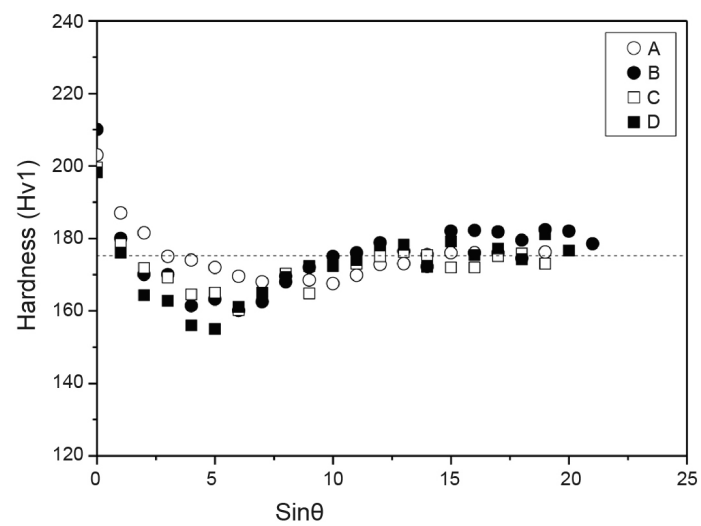

Fig. 3. Microhardness distributions of the welded joints.

다면 그에 따라 연화의 정도도 함께 달라질 것으로 추측되나 이에 대한 연구는 미흡한 실정이다.

\section{2. 실험방법}

실험에는 $0.1 \% \mathrm{C}-1.5 \% \mathrm{Mn}-0.015 \% \mathrm{Ti}$ 를 기본조성으로 $\mathrm{N}$ 을 0.003-0.024\% 변경시켜 진공용해하여 제조한 네 종류의 강을 사용하였다. 용해/응고시킨 두께 $50 \mathrm{~mm}$ 의 강괴를 균열 한 후 $760{ }^{\circ} \mathrm{C}$ 에서 $30 \%$ 압하율로 최종 두께 $12.5 \mathrm{~mm}$ 로 만든 다음 $8{ }^{\circ} \mathrm{C} / \mathrm{s}$ 의 냉각속도로 가속냉각 하였다. 냉각 후 압연판 은 평균 크기가 약 $5 \mu \mathrm{m}$ 인 아주 미세한 페라이트에 펄라이트 와 베이나이트가 소량 혼재한 조직을 나타내며, 인장강도는 약 $510 \mathrm{MPa}$, 비커스 경도는 약 $175 \mathrm{Hv}$ 이었다. 표 1 에 시험재 의 화학조성과 강도를, 그리고 그림 1 에 압연판의 대표적인 광학현미경 및 주사식 전자현미경 $(\mathrm{SEM})$ 조직사진 (강 $\mathrm{A})$ 을 나타내었다.

$\mathrm{HAZ}$ 연화를 조사하기 위하여 먼저 압연판을 두께 $11 \mathrm{~mm}$ 로 연삭한 다음 $370 \mathrm{~A}-31 \mathrm{~V}-17 \mathrm{~cm} / \mathrm{min}$ (입열량 $40 \mathrm{~kJ} / \mathrm{cm}$ )의 용 
Table 2. Tensile properties of welded-joints

\begin{tabular}{c|c|c|c}
\hline Steel & $\begin{array}{c}\text { TS } \\
(\mathrm{MPa})\end{array}$ & $\begin{array}{c}\text { YS } \\
(\mathrm{MPa})\end{array}$ & $\begin{array}{c}\text { El } \\
(\%)\end{array}$ \\
\hline $\mathrm{A}$ & 486 & 376 & 24 \\
\hline $\mathrm{B}$ & 484 & 371 & 26 \\
\hline $\mathrm{C}$ & 481 & 371 & 25 \\
\hline $\mathrm{D}$ & 479 & 365 & 24 \\
\hline
\end{tabular}

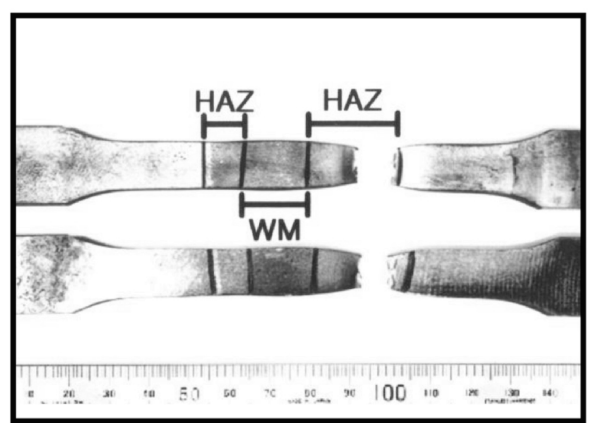

Fig. 4. Fracture location of welded joint tensile specimens.

접조건으로 1 패스 완전용입의 $\mathrm{CO}_{2}$ 용접을 행하였다. 그림 2 에 사용한 용접이음부 형상을 나타내었다. 용접된 이음부 단 면에 대하여 판두께 중앙부에서 연속 비커스경도 (하중 $1 \mathrm{~kg}$ ) 를 측정하였다. 경도측정은 최소 3 번 이상을 행하여 평균값 을 구하였다. HAZ 연화에 의한 용접이음부 파단위치 변화를 확인하기 위하여 판 두께 중심부에서 두께 $7 \mathrm{~mm}$, 표점거리 $50 \mathrm{~mm}$ 의 인장 시험편을 가공하여 인장시험도 행하였다.

광학 및 전자현미경을 사용하여 $\mathrm{HAZ}$ 조직을 관찰하였다. 특히 N 함량이 HAZ 조직변태에 미치는 영향을 조사하기 위 하여 HAZ 연속냉각변태도 (SH-CCT diagram)를 작성하였 다. 직경이 $3 \mathrm{~mm}$ 이고 길이가 $10 \mathrm{~mm}$ 인 원통형 시편을 전자 동 변태점측정장치 (FDC Formaster F)를 사용하여 $1350{ }^{\circ} \mathrm{C}$ 까지 가열하여 $5 \mathrm{~s}$ 동안 유지한 다음 800 에서 $500{ }^{\circ} \mathrm{C}$ 까지의 냉각시간 $\left(\triangle \mathrm{t}_{8 / 5}\right)$ 을 $10-100 \mathrm{~s}$ 로 냉각하면서 변태점을 측정하 였다. 한편 모재 및 $\mathrm{HAZ}$ 에서의 TiN 석출물은 탄소추출레플 리카를 이용한 투과식 전자현미경 (STEM, JEOL JEM $2100 \mathrm{~F})$ 으로 관찰하였다. 시야 수를 무작위로 10 번 이상으로 하여 STEM 사진을 촬영한 다음, 확대한 사진을 이용하여 각 형의 형상을 가지는 석출물을 대상으로 짧은 변의 길이를 측 정하여 크기를 나타내었다.

\section{3. 실험결과 및 고찰}

$\mathrm{CO}_{2}$ 용접한 용접이음부 단면을 사용하여 용융선에서 모

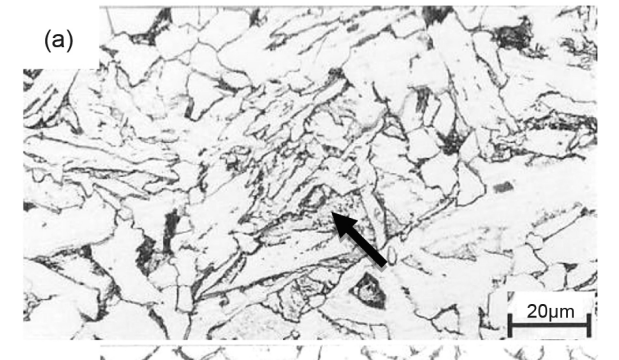

(b)

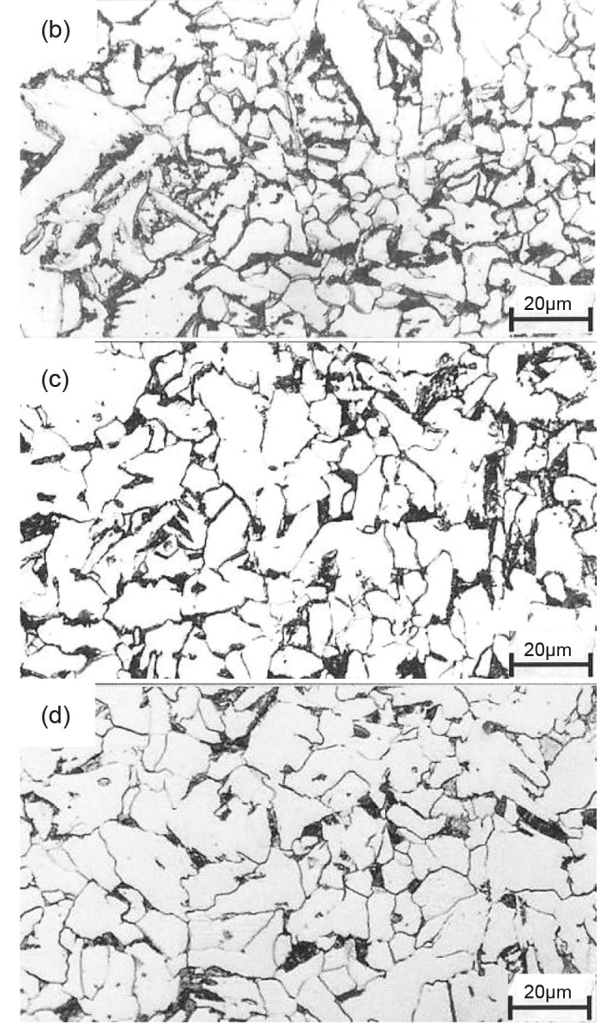

Fig. 5. Comparison of optical microstructures in the softened zone. (a) steel A, (b) steel B, (c) steel C, and (d) steel D.

재 쪽으로 연속경도를 측정한 결과를 그림 3 에 나타내었다. 모든 강들은 용융선에서 $200 \mathrm{Hv}$ 이상의 높은 경도를 나타낸 후 저하하여 2-3 mm 떨어진 곳에서부터 파선으로 표시한 모 재 경도인 $175 \mathrm{Hv}$ 보다 낮은 연화영역을 나타내기 시작한다. 강 종별로 약간의 차이는 있으나 약 9-10 mm 폭의 연화영역 을 나타낸 후, 11-12 mm 부근에서부터 다시 모재 경도에 근 접한다. 그림 4에 대표적으로 $\mathrm{C}$ 강의 용접이음부 인장시험 후 파단 모습을 나타내었다. 파단이 모재가 아닌 HAZ에서 일어나 연화영역의 존재에 의한 용접이음부 강도 저하를 확 인할 수 있다. 표 2에 각 강들의 용접이음부 강도를 나타내었 다. 한편 연화영역에서 연화의 정도를 나타내는 최저경도는 강 종별로 차이를 보여 $\mathrm{N}$ 함량이 가장 낮은 $\mathrm{A}$ 강이 $165 \mathrm{Hv}$ 로 


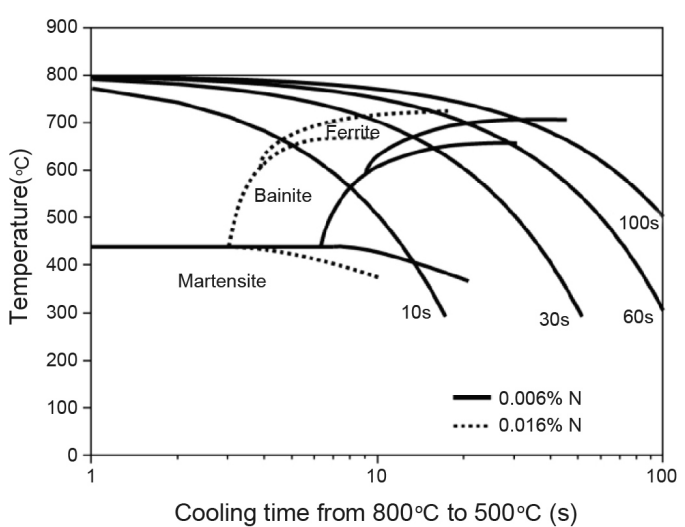

Fig. 6. Comparison of SH-CCT diagrams between $0.006 \% \mathrm{~N}$ steel and $0.016 \% \mathrm{~N}$ steel.

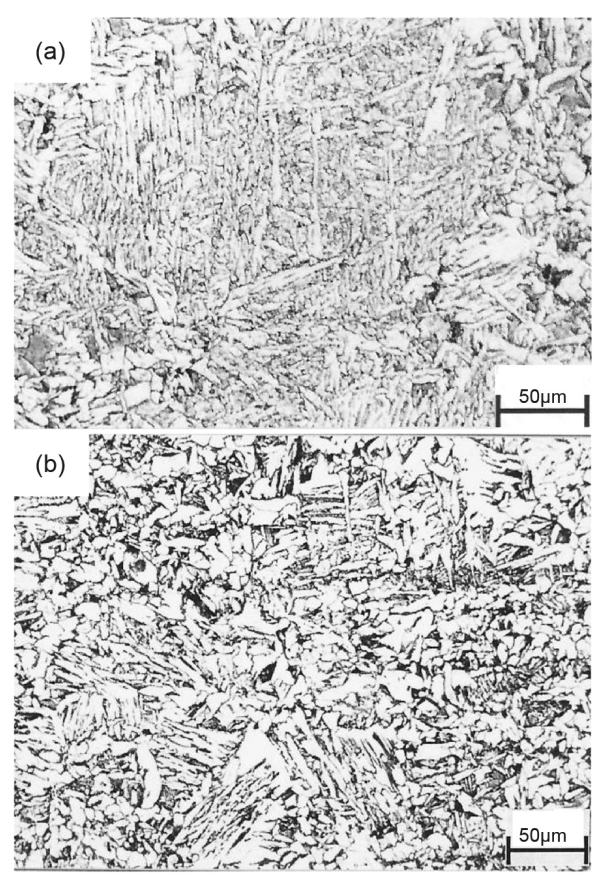

Fig. 7. Comparison of optical microstructures after weld cooling cycle ( $\triangle \mathrm{t} 8 / 560 \mathrm{~s}$ ). (a) $0.006 \% \mathrm{~N}$ steel, (b) $0.016 \% \mathrm{~N}$ steel.

가장 높았고, 가장 높은 D 강이 $154 \mathrm{Hv}$ 로 가장 낮았다. 즉 N 함량의 증가에 따라 연화의 정도가 더욱 커짐을 나타내었다. 그림 5에 최저경도를 나타내는 부근인 용융선에서 약 $4 \mathrm{~mm}$ 떨어진 곳에서의 광학현미경 조직사진을 비교하였다. 모든 강에서 페라이트 크기는 약 10-20 $\mu \mathrm{m}$ 로 모재의 $5 \mu \mathrm{m}$ 에 비하 여 크게 성장하여 있다. 하지만 페라이트와 함께 혼재하는 베 이나이트 양에는 큰 차이를 나타낸다. 즉 $\mathrm{N}$ 함량이 가장 작은 $\mathrm{A}$ 강에서는 (그림 a) 그림 중에 화살표로 표시한 베이나이트 가 상당량 혼재하여 있으나, 가장 큰 $\mathrm{D}$ 강에서는 (그림 $\mathrm{d}$ ) 거

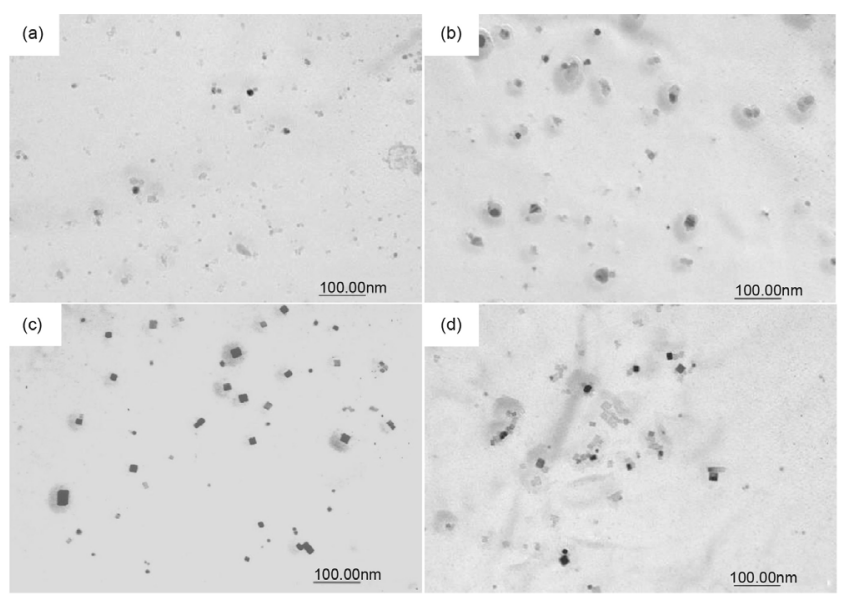

Fig. 8. Typical TEM micrographs of carbon extraction replicas. (a) $0.006 \% \mathrm{~N}$ steel, base plate, (b) $0.016 \% \mathrm{~N}$ steel, base plate, (c) $0.006 \% \mathrm{~N}$ steel, HAZ, and (d) $0.016 \% \mathrm{~N}$ steel, HAZ.

의 보이지 않는다. 따라서 $\mathrm{N}$ 함량의 증가에 따라 연화의 정도 가 증가하는 것은 상대적으로 경한 조직인 베이나이트의 감 소가 한 원인임을 알 수 있다.

최저경도는 그림 3에서 보는 바와 같이 용융선에서 약 4 $\mathrm{mm}$ 떨어진 곳에서 나타난다. 이런 가열온도가 낮은 곳에서 는 $\mathrm{D}$ 강의 경우 $\mathrm{N}$ 함량의 증가에 기인하는 변태온도의 저하 로 가열과정 중 쉽게 오스테나이트로 역변태한 후 냉각과정 중 미세 페라이트로 변태할 가능성이 있다. 하지만 그림 3에 서 보는 바와 같이 $\mathrm{D}$ 강은 용융선에서부터 시작하여 최저경 도를 나타내는 곳까지 전 영역에 걸쳐 가장 낮은 경도를 나타 낸다. 즉 저온가열되는 곳뿐만 아니라 고온가열되는 곳에서 도 질소가 많으면 낮은 경도를 나타낸다. 따라서 논의의 편의 를 위하여 고온가열 $\mathrm{HAZ}$ 를 가정하여 $\mathrm{N}$ 함량이 $\mathrm{HAZ}$ 조직변 태에 미치는 영향을 더욱 상세히 조사하였다. $0.1 \% \mathrm{C}$ $1.5 \% \mathrm{Mn}-0.02 \% \mathrm{Ti}$ 를 기본조성으로 $\mathrm{N}$ 함량을 각각 $0.006 \%$ 및 $0.016 \%$ 로 변경시킨 두 강을 시험재와 동일한 방법으로 제 조한 다음 각각에 대하여 SH-CCT도를 작성하였다. 실험방 법에서 설명한 것처럼 각 시편을 $1350{ }^{\circ} \mathrm{C}$ 까지 가열하여 5 초 간 유지한 다음 $\triangle \mathrm{t}_{8 / 5}$ 를 $10-100 \mathrm{~s}$ 로 냉각하는 도중 전자동변 태점 측정장치를 사용하여 각각의 변태점을 측정하였다. 몇 몇의 경우에는 측정한 변태점 부근에서 시편을 급냉한 후 조 직관찰을 행하여 더욱 정확한 변태온도를 결정하였다. 그림 6에 두 강의 SH-CCT도를 비교하였다. N 함량이 $0.016 \%$ 인 강이 $0.006 \%$ 인 강에 비하여 $\mathrm{CCT}$ 도가 단시간 측으로 이동하 여 페라이트 변태가 촉진되고 있음을 알 수 있다. 그림 7에는 대표적으로 $\triangle \mathrm{t}_{8 / 5}$ 를 $60 \mathrm{~s}$ 로 냉각한 경우 두 강의 광학현미경 
Table 3. Mean particle sizes and number densities of TiN particles in the base plate and HAZ.

\begin{tabular}{c|c|c|c|c}
\hline \multirow{2}{*}{$\begin{array}{c}\text { N content } \\
(\text { wt.\%) }\end{array}$} & $\begin{array}{c}\text { Mean } \\
\text { particle } \\
\text { size }(\mathrm{nm})\end{array}$ & $\begin{array}{c}\text { Number } \\
\text { density } \\
\left(/ \mathrm{mm}^{2}\right)\end{array}$ & $\begin{array}{c}\text { Mean } \\
\text { particle } \\
\text { size }(\mathrm{nm})\end{array}$ & $\begin{array}{c}\text { Number } \\
\text { density } \\
\left(/ \mathrm{mm}^{2}\right)\end{array}$ \\
\hline 0.006 & 7.2 & $2.1 \times 10^{8}$ & 16.8 & $0.3 \times 10^{8}$ \\
\hline 0.016 & 8.4 & $1.7 \times 10^{8}$ & 10.3 & $1.1 \times 10^{8}$ \\
\hline
\end{tabular}

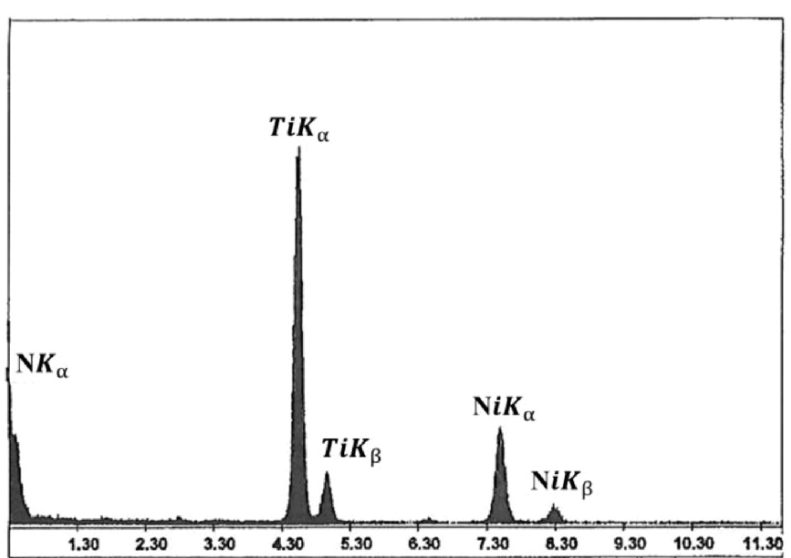

Fig. 9. EDX spectrum of the precipitates

조직을 비교하였다. $\mathrm{N}$ 함량이 $0.006 \%$ 인 강은 (그림 a) 베이 나이트가 대부분이며 페라이트가 소량인 조직을 나타내나, $0.016 \%$ 인 강은 (그림 b) 페라이트 변태의 촉진으로 대부분이 페라이트인 조직을 나타내고 있다.

용접냉각 중 HAZ에서 오스테나이트로부터 페라이트로의 변태는 오스테나이트 크기에 영향을 받으며, 오스테나이트 크기는 석출물의 크기와 분포에 영향을 받는다고 잘 알려져 있다. 본 연구에서는 $\mathrm{TiN}$ 석출물 관찰을 행하여 $\mathrm{N}$ 함량이 석 출물의 크기와 분포에 미치는 영향을 조사하였다. 두 강의 압 연판 및 $\mathrm{HAZ}\left(\triangle \mathrm{t}_{8 / 5}=60 \mathrm{~s}\right)$ 에서 추출레플리카에 의한 TiN 석 출물을 관찰한 대표적인 결과를 그림 8 에 나타내었다. 석출 물의 에너지분산X선 $(\mathrm{EDX})$ 분석결과를 그림 9 에 나타내었 는데 TiN 석출물임을 확인할 수 있다. 그림 중 $\mathrm{Ni}$ 피크는 그 리드 때문이다. 무작위로 10 번 이상 관찰한 이러한 사진을 확 대하여 석출물의 평균크기 및 수 밀도 (number density)를 구 하였다. 그림 10 에 석출물들의 크기분포를, 표 3에는 평균크 기 및 수 밀도를 정리하여 나타내었다. 압연판의 경우에는 N 함량이 $0.006 \%$ 인 강에서 각각 $7.2 \mathrm{~nm}$ 와 $2.1 \times 10^{8} / \mathrm{mm}^{2}$, $0.016 \%$ 인 강에서 $8.4 \mathrm{~nm}$ 와 $1.7 \times 10^{8} / \mathrm{mn}^{2}$ 을 나타내어 두 강 사이에 큰 차이를 보이지 않는다. 하지만 HAZ에서는 각각
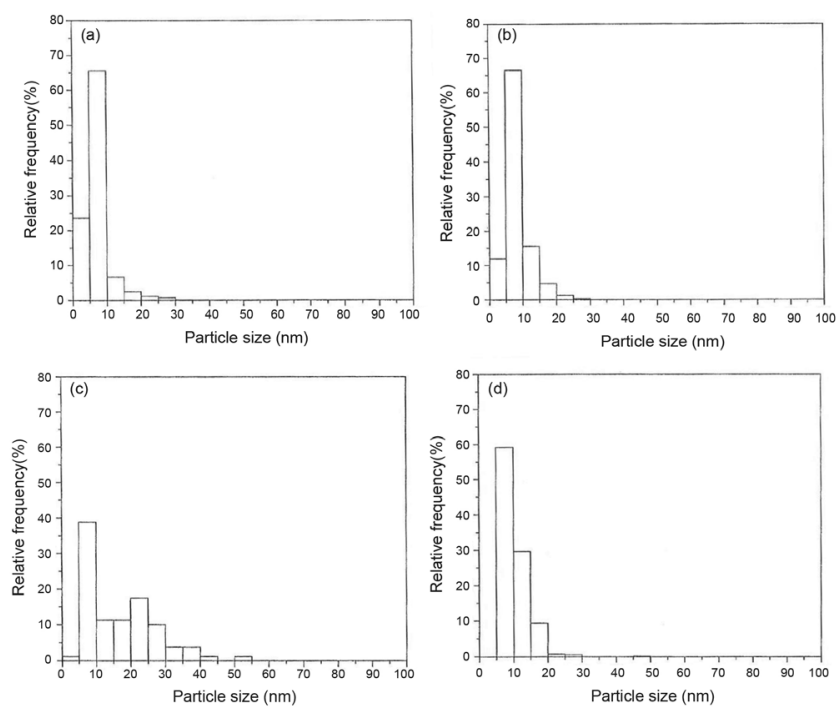

Fig. 10. Precipitate size distributions. (a) $0.006 \% \mathrm{~N}$ steel, base plate, (b) $0.016 \% \mathrm{~N}$ steel, base plate (c) $0.006 \% \mathrm{Nsteel}, \mathrm{HAZ}$, and (d) $0.016 \%$ Nsteel, HAZ

$16.8 \mathrm{~nm}$ 와 $0.3 \times 10^{8} / \mathrm{mm}^{2}, 10.3 \mathrm{~nm}$ 와 $1.1 \times 10^{8} / \mathrm{mm}^{2}$ 를 나타내 어 두 강 사이에 차이를 나타낸다. 먼저 두 강 모두 압연판에 비하여 HAZ에서 석출물이 횔씬 커져 있어 용접과정 중 TiN 의 조대화를 확인할 수 있다. 하지만 조대화의 정도는 $\mathrm{N}$ 함량 이 $0.016 \%$ 인 강이 $0.006 \%$ 인 강에 비하여 훨씬 작음을 알 수 있다.

이러한 $\mathrm{N}$ 함량 증가에 따른 $\mathrm{TiN}$ 석출물 조대화 억제효과 는 앞선 연구에서도 보고되고 있다 [12,13]. 본 연구에서는 $\mathrm{HAZ}$ 에서 TiN 조대화에 미치는 N 함량의 영향을 TiN 용해도 곡선을 이용하여 살펴 보았다. 그림 11 에 $1350{ }^{\circ} \mathrm{C}$ 에서 $\mathrm{TiN}$ 용해도곡선을 나타내었다. 이때 사용한 용해도 식은 다음과 같다.

$\log [\mathrm{Ti} \%][\mathrm{N} \%]=-16192 / \mathrm{T}+4.72$

그림 중에는 두 강의 $\mathrm{TiN}$ 석출선을 같이 나타내었다. 각 경 우에 있어서 용해도 곡선과 석출선의 교점은 $\mathrm{HAZ}$ 에서 고용 된 상태로 존재하는 $\mathrm{Ti}$ 와 $\mathrm{N}$ 의 함량을 뜻한다. 고용된 $\mathrm{Ti}$ 와 $\mathrm{N}$ 함량을 비교하면 $\mathrm{N}$ 함량이 $0.006 \%$ 인 강이 각각 $0.0041 \%$ 와 $0.0013 \%, 0.016 \%$ 인 강이 $0.0005 \%$ 와 $0.0103 \%$ 이다. 고용된 $\mathrm{Ti}$ 함량만을 보면 $\mathrm{N}$ 함량이 $0.016 \%$ 로 높은 강이 훨씬 작다. 이러한 기지 중 용질원자의 고용농도가 석출물의 조대화, 즉 Ostwald ripening에 미치는 영향은 잘 알려져 있다. 용질원자 의 확산이 석출물의 성장속도를 율속한다면 석출물의 조대 


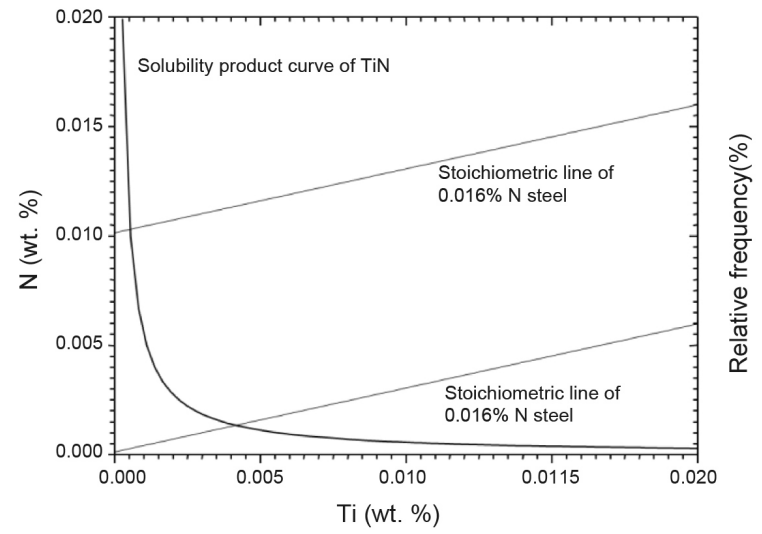

Fig. 11. Solubility diagram for titanium nitride, showing the effect of nitrogen content in the steel on the soluble solute contents in the HAZ.

화는 일반적으로 다음 식으로 표현된다.

$$
r^{3}-r 0^{3}=8 \mathrm{D} \gamma \Omega X \mathrm{t} / 9 \mathrm{RT}
$$

여기서 $\mathrm{r}$ 은 시간 $\mathrm{t}$ 에 있어서 석출물의 반경, $\mathrm{r}_{0}$ 는 시간 $\mathrm{t}=0$ 에 있어서 석출물의 반경, $\mathrm{D}$ 는 용질원자의 확산계수, $\gamma$ 는 석출물 과 기지의 계면에너지, $\mathrm{X}$ 는 평균크기의 석출물과 평형을 이 루는 용질원자의 농도, $\mathrm{R}$ 은 가스정수, T는 절대온도다. TiN 석출물의 경우 용질원자는 $\mathrm{Ti}$ 와 $\mathrm{N}$ 이나 $\mathrm{Ti}$ 의 확산계수가 $\mathrm{N}$ 보 다 훨씬 작음을 감안하면 조대화를 율속하는 용질원자는 $\mathrm{Ti}$ 이다. 즉 고용된 $\mathrm{Ti}$ 함량이 작을수록 $\mathrm{TiN}$ 의 성장을 억제할 수 있다. 이런 이유로 그림 8 에서 보는 바와 같은 $\mathrm{N}$ 함량이 큰 $0.016 \%$ 인 강에서의 $\mathrm{TiN}$ 의 조대화 억제는 낮은 고용 $\mathrm{Ti}$ 함량 때문이다. 크기가 작은 석출물들이 결정립 성장을 더욱 효과 적으로 억제함을 감안하면, $\mathrm{N}$ 함량이 클수록 $\mathrm{HAZ}$ 에서 페라 이트 변태가 촉진되는 것은 이러한 $\mathrm{TiN}$ 석출물의 조대화 억 제에 의한 오스테나이트 결정립의 미세화 효과 때문으로 판 단된다. 질소 함량의 증가에 기인한 오스테나이트 결정립 미 세화는 다른 실험결과에서도 [14] 확인되고 있다. 한편 질소 는 오스테나이트 안정화 원소로 변태를 지연시키는 효과를 나타낸다는 점을 감안하면, 본 실험에서 질소 증가에 따른 페 라이트 변태의 촉진은 TiN에 의한 오스테나이트 크기 억제 효과가 오스테나이트 안정화 효과보다 훨씬 크기 때문인 것 으로 판단된다. 이상의 실험결과는 HAZ에서의 인성 향상을 위하여 $\mathrm{Ti}$ 을 첨가한 강을 강압하/가속냉각으로 제조하는 경 우, $\mathrm{N}$ 함량이 지나치게 높으면 용접 후 연화의 정도가 더욱 커 짐을 나타내어 강재의 성분설계 시 주의를 요함을 나타낸다.

\section{4. 결 론}

$\mathrm{Ti}$ 을 첨가하여 강압하/가속냉각으로 제조한 인장강도 500 $\mathrm{MPa}$ 급 고장력강의 $\mathrm{N}$ 함량이 $\mathrm{HAZ}$ 연화에 미치는 영향을 조 사한 결과 다음과 같은 결론을 얻었다.

(1) $0.003-0.024 \%$ 의 N 함량에 관계 없이 모든 강들은 9-10 $\mathrm{mm}$ 폭의 연화영역을 나타내었으며, 용접이음부 인장시험 결과 모재가 아닌 HAZ에서 파단하였다. 연화영역에서 최저 경도는 $\mathrm{N}$ 함량이 가장 낮은 강이 $165 \mathrm{Hv}$ 로 가장 높았고, 가 장 높은 강이 $154 \mathrm{Hv}$ 로 가장 낮았다. 즉 $\mathrm{N}$ 함량의 증가에 따 라 연화의 정도는 더욱 커졌다.

(2) 연화영역에서 조직 관찰 결과 $\mathrm{N}$ 함량의 증가에 따라 베이나이트가 감소하고 대부분이 페라이트인 조직을 보여, $\mathrm{N}$ 함량 증가에 따른 최저경도의 저하는 용접냉각과정 중 $\mathrm{HAZ}$ 에서 페라이트 변태의 촉진이 한 원인임을 나타내었다.

(3) $\mathrm{N}$ 함량이 높을수록 HAZ에서 낮은 고용 $\mathrm{Ti}$ 함량을 나 타내어 TiN 석출물의 조대화가 억제되었다. 따라서 $\mathrm{N}$ 함량 이 높은 강에서의 페라이트 변태의 촉진은 미세한 TiN에 의 한 오스테나이트 성장의 억제 때문인 것으로 판단된다.

\section{감사의 글}

이 논문은 부경대학교 자율창의학술연구비(2016년)에 의 하여 연구되었음.

\section{REFERENCES}

1. N. Yurioka, Weld. World. 33, 34 (1994).

2. O. M. Akselsen and G. Rorvik, Mat. Sci. Tech. 6, 383 (1990).

3. O. M. Akselsen, G. Rorvik, M. I. Onsoien, and O. Grong, Weld. J. 69, 356-s (1989).

4. H. Nitoh, D. Sakai, H. Yajima, Y. Inoue, Y. Soga, K. Satoh, and M. Toyoda, J. Soc. of Naval Arch. Jap. 1985, 304 (1985).

5. N. Yurioka, Weld. Tech. Jan,160 (1994).

6. S. C. Wang, Mat. Sci. Eng. A 145, 87 (1991).

7. M. Doi, S. Endo, and K. Osawa, Q. J. Jpn. Weld. Soc. 17, 440 (1999).

8. Y. Kasamatsu, S. Takashima, and T. Hosoya, Tetsu-toHagane. 65, 1232 (1979).

9. J. K. Choi, Proc. 1st Int. Conf. on Super High Strength Steels. p. 135, Associazione Italiana di Metallurgia, Rome, Italy (2005).

10. K. T. Park, S. W. Hwang, J. H. Ji, and C. H. Lee, Met. Mater. Int. 17, 349 (2011). 
11. H. K. Sung, S. Y. Shin, W. Cha, K. Oh, S. Lee, and N. J. Kim, Korean J. Met. Mater. 48, 875 (2010).

12. B. Loberg, N. Nordgren, J. Strid, and K. E. Easterling, Metall. Trans. 15A, 33 (1984).

13. H. Adrian, Proc. Int. Conf. on Microalloying 95. (eds.
M. Korchynsky, A.J. DeArdo, P. Repas, and G. Tither), p. 285, Iron and Steel Soc. Inc., Pittsburg, USA (1995).

14. H. C. Jeong, Y. H. An, and W. Y. Woo, Int. J. of KWS. 2, 23 (2002). 